\title{
First Nations, Metis, AND InUIT Women's Health: A Rights-BASED APPROACH
}

\author{
YVONNE BOYER ${ }^{*}$
}

\begin{abstract}
The health status of Aboriginal women in Canada is disparagingly low as compared to the non-Aboriginal population. The implementation of male centred legislation, policies, and institutions that are the hallmark of Canada's colonial history have had a long-lasting impact on the health of Aboriginal women. Although Aboriginal women have unique sets of constitutionally protected rights, the government has failed to protect these rights.
\end{abstract}

The purpose of this article is to present a constitutional and human rights-based approach to address constitutionally protected rights within the context of a distinctive Indigenous appreciation of social rights and of women's substantive equality. This article is separated into three sections. First, using data from federal government and the Native Women's Association of Canada statistics, the health status of Aboriginal women is examined. Many international instruments and agreements recognize a rights-based approach to health. Canada, as a signatory to a number of these agreements, has acknowledged its international obligations towards the health of Aboriginal people. Two of these agreements, the Universal Declaration of Human Rights and the United Nations Declaration on the Rights of Indigenous People, provide the human rights standards that bind Canada with regard to all Canadians and are examined in the second section. The last section suggests that a constitutional equality rights framework may offer a promising basis for future right to health assertions by Aboriginal women. Through an analysis of both collective and individual rights of Aboriginal women to health, section 35 of the Constitution Act, 1982, and the Canadian Charter of Rights and Freedoms, it becomes apparent that Canada is in breach of its constitutional obligations.

\section{TABLE OF CONTENTS}

I. INTRODUCTION . . . . . . . . . . . . . . . . . . . 612

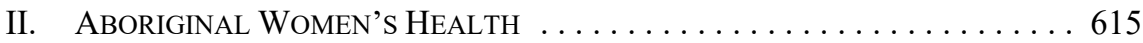



B. TRuth AND RECONCILIATION CALls to ACtion . . . . . . . . . 619

III. A RightS-BASEd APPROACH tO HeALTh . . . . . . . . . . . . . . . . 619

A. UNIVERSAL DECLARATION OF HUMAN RIGHTS . . . . . . . . . . 622

B. UNITED NATIONS DECLARATION

ON THE RIGHTS OF INDIGENOUS PEOPLES . . . . . . . . . . 623

IV. The CONSTITUtion, AbORiginal Rights,

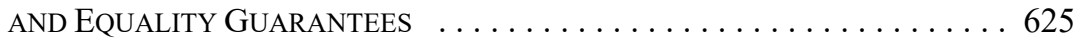

A. Aboriginal Women's Equality Rights as Individuals . . . . . . 626

B. Aboriginal Women's Collective Equality Rights . . . . . . . 627



Canada Research Chair in Aboriginal Health and Wellness; Professor, Native Studies, Faculty of Arts, Brandon University. Portions of this article were previously published by the author through the Native Law Centre and the National Aboriginal Health Organization, in a 2006 paper titled First Nations, Métis and Inuit Women's Health, in the Discussion Paper Series: Aboriginal Health: Legal Issues. 


\title{
I. INTRODUCTION
}

In 1946, the World Health Organization (WHO) adopted a broad definition of health, moving from an "absence of disease" model to one that encompasses "[a] state of complete physical, mental and social well-being and not merely the absence of disease or infirmity." The emergence of the WHO definition signaled "an integrated approach linking together all the factors related to human well-being, including physical and social surroundings conducive to good health.,"2

Historically, Aboriginal peoples ${ }^{3}$ have always understood and practiced an integrated approach to health. The Royal Commission on Aboriginal Peoples (RCAP) summarizes the centrality of health to the total well-being of Aboriginal peoples in Canada:

\begin{abstract}
In the imagery common to many Aboriginal cultures, good health is a state of balance and harmony involving body, mind, emotions and spirit. It links each person to family, community and the earth in a circle of dependence and interdependence, described by some in the language of the Medicine Wheel. In nonAboriginal terms, health has been seen primarily as an outcome of medical care. But we are quickly learning that any care system that reduces its definition of health to the absence of disease and disability is deeply flawed. ${ }^{4}$
\end{abstract}

However, by all health status indicators, Aboriginal peoples in Canada suffer from disproportionately poor health compared to the non-Aboriginal population ${ }^{5}$ due to a long history of colonialist policies, for instance the residential schools system. The negative impacts of the child welfare system, overrepresentation in the justice system, chronic low income and poverty, substandard housing, lack of self determination, and unequal standards of education all contribute to ill health.

For example, the life expectancy of First Nations and Metis people is approximately four to seven years less than the Canadian average ${ }^{6}$ and 12 years less in Inuit-inhabited areas. ${ }^{7}$ Inuit infant mortality rates are four times the Canadian average. ${ }^{8}$ Suicide rates for First

World Health Organization, Constitution of the World Health Organization in Basic Documents, 48th ed (WHO, 2014) 1 at 1 [WHO]. The organization's main objective is the "attainment by all peoples of the highest possible level of health" (ibid, art 2).

Enrique González, "Module 14: The Right to Health," Circle of Rights: Economic, Social \& Cultural Rights Activism: A Training Resource (University of Minnesota Human Rights Resource Center, 2000), online: <https://www1.umn.edu/humanrts/edumat/IHRIP/circle/modules/module14.htm> . This article uses the term "Aboriginal peoples" as a collective name for the original people in Canada. This term is also used as per section 35(2) of the Constitution Act, 1982, being Schedule B to the Canada Act 1982 (UK), 1982, c 11. The term "Aboriginal peoples of Canada" in the Constitution Act, 1982 refers to the "Indian, Inuit, and Métis." The terms "First Nations," "Metis," and "Inuit" are used interchangeably with the term "Aboriginal," where applicable. The term "Native" is used where it is historically appropriate. The term "Indigenous" is used in a global sense.

$4 \quad$ Canada, Royal Commission on Aboriginal Peoples, Report of the Royal Commission on Aboriginal Peoples, vol 3, Gathering Strength (Ottawa: Supply and Services Canada, 1996) at 139 [RCAP].

Lisa M Lix et al, Statistics Canada, "Risk Factors and Chronic Conditions Among Aboriginal and NonAboriginal Populations" (2009) 20: 4 Health Reports 21.

$6 \quad$ Michael Tjepkema \& Russell Wilkins, "Remaining Life Expectancy at Age 25 and Probability of Survival to Age 75, By Socio-economic Status and Aboriginal Ancestry" (2011) 22:4 Health Reports 31 .

$7 \quad$ Russell Wilkins et al, "Life Expectancy in the Inuit-Inhabited Areas of Canada: 1989 to 2003" (2008) 19:1 Health Reports 7.

8 Janet Smylie et al, “A Review of Aboriginal Infant Mortality Rates in Canada: Striking and Persistent Aboriginal/Non-Aboriginal Inequities" (2010) 101:2 Can J Pub Health 143 at 146. 
Nations youth are five to six times higher than for non-Aboriginal youth, while the rate among Inuit youth is among the highest in the world, at 11 times the national rate. ${ }^{9}$ Aboriginal peoples in Canada also suffer a greater incidence of ill health throughout their lives when compared with non-Aboriginal Canadians. This is evidenced by higher rates of chronic and infectious diseases as well as obesity among Aboriginal people. ${ }^{10}$ The prevalence of diabetes among First Nations is three times the national average, and the tuberculosis rates for Inuit are three times higher than for First Nations and 70 times the rate for non-Aboriginal Canadians. ${ }^{11}$

The situation for Aboriginal women is even more appalling. Theirs is a well-documented experience of violence, discrimination, inequality, sexual harassment, and oppression. ${ }^{12}$ The resulting harmful consequences affect not only their health and well-being, but also impinge on the lives of their children, family, and community members. ${ }^{13}$ The male centred legislation, policies, and institutions that are the hallmark of Canada's colonial history have had a long-lasting negative effect on the health of Aboriginal women. In Canadian society, women's inequality has been entrenched through well-intentional laws that have had a discriminatory impact. These laws regulate areas such as contraception, abortion, ${ }^{14}$ sexual assault, ${ }^{15}$ obscenity, and medical practice, and the provision of a wide range of health services. Meanwhile, the Indian Act ${ }^{16}$ the residential schools system, sterilization laws, mental health laws, forced removal of children, and enfranchisement were tools that attacked the essence of Aboriginal women as caregivers, leaders, and equal members of the community. ${ }^{17}$ The aggregate of these laws and policies has helped perpetuate women's inequality in the area of health care and services. ${ }^{18}$

Health Canada, "First Nations and Inuit Health: Mental Health and Wellness," online: <www.hcsc.gc.ca/ fniah-spnia/promotion/mental/index-eng.php>.

10 J Reading, The Crisis of Chronic Disease Among Aboriginal Peoples: A Challenge for Public Health, Population Health and Social Policy (University of Victoria Centre for Aboriginal Health Research: 2009) at 10, online: <cahr.uvic.ca/nearbc/documents/2009/CAHR-B2-Chronic-Disease.pdf>; Public Health Agency of Canada, Diabetes in Canada: Facts and Figures from a Public Health Perspective" (Ottawa: PHAC, 2011) at 95, online: <publications.gc.ca/collections/Collection/H35-4-6-2001E.pdf> [PHAC].

$11 \quad$ PHAC, ibid at 92.

12 Statistics Canada, Aboriginal Identity Population by Age Groups, Median Age and Sex, 2006 Counts for Both Sexes, for Canada, Provinces and Territories (Ottawa: Statistics Canada, 2007) (the "average" Aboriginal woman in a penitentiary is 27 years old, with a limited education (usually grade nine), is unemployed or under-employed, and the sole support mother to two or three children. She is usually unemployed at the time she is arrested); Canadian Association of Elizabeth Fry Societies, "Indigenous Women," online: <www.caefs.ca/wp-content/uploads/2013/05/FINAL-2015-Fact-Sheet-IndigenousWomen.pdfs.

13 Carrie Bourassa, Kim McKay-McNabb \& Mary Hampton, "Racism, Sexism, and Colonialism: The Impact on the Health of Aboriginal Women in Canada" (2004) 24:1 Can Women's Studies 23 at 28.

Jessica Shaw, "Abortion as a Social Justice Issue in Contemporary Canada" (2013) 14:2 Critical Social Work 2.

15 Kirk Makin, "How Canada's Sex-Assault Laws Violate Rape Victims," The Globe and Mail (5 October 2013), online: <www.theglobeandmail.com/news/national/how-canadas-sex-assault-laws-violate-rapevictims/article $14705289 /$ ?page $=$ all $>$.

RSC 1985, c I-5.

Bourassa, McKay-McNabb \& Hampton, supra note 13 at 28.

This fundamental inequality is exacerbated by the fact that, in approaching women's health, health care services are, and have been, provided from a male centred perspective. Substantive rights continue to elude women in the area of health, although changes in Canadian laws in the past few decades have alleviated some of the more contentious health-related legal controls on women. 
The following are some examples of how Canadian laws and policies have led to the depreciation of Aboriginal women's health and well-being. First we have the overrepresentation of Aboriginal women who are being trafficked in Canada. ${ }^{19}$ Research shows that there is a direct correlation between being sexually abused as children and working in the sex trade..$^{20}$ Between 80 and 90 percent of Aboriginal women involved in the sex trade were sexually abused as children, with most offenders being family members or foster care parents. ${ }^{21}$ Experts have explained that a history of child abuse in Aboriginal children is almost always related to the intergenerational effects of residential schools. Canadian laws forced Aboriginal children into residential schools, causing devastation that continues to impact the self-esteem and self-worth of Aboriginal women. Violence and sexual exploitation is all too common. Compounding this is the fact that when Aboriginal women report abuse, they are often not believed, or are seen as lacking credibility by the Canadian judicial system..$^{22}$ As an example, during the murder trial of Pamela George, an Aboriginal woman who had been murdered by two white male university students, Justice Ted Malone reminded the jury in his instructions that she was "indeed a prostitute." ${ }^{23}$ Instead of protecting and serving Aboriginal women, the Canadian justice system continues to oppress them through inadvertent discrimination and sexism.

The second example is connected to the first and relates to the current prostitution laws in Canada. Despite the Supreme Court of Canada striking down anti-prostitution laws for being unconstitutional in the case of Canada (Attorney General) v. Bedford, the Harper Government made buying sex illegal. Because it is illegal to buy sex, the working conditions for sex-trade workers continue to be unsafe, with women often forced into back alleyways, away from protection. Human rights lawyer Nicole Barrett has done extensive research on the disproportionate amount of Aboriginal women involved in the sex trade. In her literature review done in 2010, she stated that, "[s]tudies on human trafficking in Canada [concluded] that the majority of people trafficked within Canada are Aboriginal women and children victims of sex trafficking." 24 These laws directly impact Aboriginal women who are involved in the sex trade.

Finally, there is the case of Brenda Pelletier, a Metis woman from Saskatchewan who was coerced by medical staff and social workers into having tubal litigation surgery against her will. ${ }^{25}$ After giving birth to her seventh child in 2010, Pelletier was approached by a social worker along with nurses who asked her to sign the consent form to have the sterilization procedure. Pelletier refused. The following morning, a nurse informed Pelletier that they had

Native Women's Association of Canada, "Sexual Exploitation and Trafficking of Aboriginal Women and Girls: Literature Review and Key Informant Interviews" (October 2014) at 44. Ibid at 9.

Yvonne Boyer \& Peggy Kampouris, Trafficking of Aboriginal Women and Girls (Her Majesty the Queen in Right of Canada, May 2014) prepared for Research and Analysis Division, Community Safety and Countering Crime Branch, Public Safety Canada at 19. Ibid at 29 .

Maryanne Pearce, An Awkward Silence: Missing and Murdered Vulnerable Women and the Canadian Justice System (PhD Thesis, University of Ottawa, Faculty of Law, 2013) at 71 [unpublished].

Nicole A Barrett, "An Exploration of Promising Practices in Response to Human Trafficking in Canada" (Vancouver: International Centre for Criminal Law Reform and Criminal Justice Policy, 2010) at iii. Betty Ann Adam, "Saskatchewan Women Pressured to Have Tubal Ligations," Saskatoon StarPhoenix (17 November 2015) online: <www.thestarphoenix.com/news/national/women-pressured-to-have-tuballigations $>$. 
prepared an operating room for her procedure. ${ }^{26}$ The social worker returned with a doctor who gave her the consent form to sign. Fed up with being bothered, Pelletier signed the consent form on the understanding that the procedure could be reversed. ${ }^{27}$ During the operation, Pelletier said, "I don't want to," but because the health care professionals determined that she had signed the consent form, they proceeded with the sterilization surgery anyways. ${ }^{28}$ Under current standards set out by the United Nations, consent must be given "free, prior and informed." 29 In the case of Pelletier, her consent was not given freely, prior, or informed. She did not understand that the procedure was irreversible and was under considerable duress and coercion from medical staff. This procedure was illegal and resulted in a gross and traumatizing assault on her physical body by medical professionals.

Between 1970 and 1975, there were roughly 1,200 forced sterilizations of women across Canada, with a large percentage of these women being Aboriginal. ${ }^{30}$ These sterilizations were performed in accordance with provincial legislation that was enacted to prevent medical defectives. Although the Canadian government did not outwardly sanction these practices, it provided funding to the provinces that allowed sterilizations to be performed more easily. Expert on forced sterilization Karen Stote explains that, " $[\mathrm{t}]$ he ideology that justified historic coerced sterilization continues to shape state and medical interventions in the reproductive lives of women, (especially) marginalized, racialized and Indigenous women, pressuring them to get sterilized for their own good." 31

The purpose of this article is to present a constitutional rights-based approach to address the constitutional and human rights violations, within the context of a distinctive Indigenous appreciation of social rights and of women's substantive equality. The first section of the article will examine the health status of Aboriginal women. The second section sets out the rights-based approach to health, which Canada is bound to under international law. The final section suggests that a constitutional equality rights framework may offer a promising basis for future right to health claims by Aboriginal women.

\section{Aboriginal Women's Health}

As outlined above, Aboriginal women suffer disproportionately from violence and sexual exploitation. Even if an Aboriginal woman manages to escape death by violence or "disappearance," 32 she is likely to experience a variety of problems that will negatively

Ibid.

Ibid.

Ibid.

See United Nations, Department of Economic and Special Affairs, An Overview of the Principle of Free, Prior and Informed Consent and Indigenous Peoples in International and Domestic Law and Practices (New York: UN, 2005).

30 Karen Stote, An Act of Genocide: Colonialism and the Sterilization of Aboriginal Women (Halifax: Fernwood Publishing, 2015).

31 Betty Ann Adam, "Saskatoon Health Region Apologizes After Aboriginal Women Felt Pressured by Staff to Have Tubes Tied," The National Post (17 November 2015), online: <news.nationalpost.com/ news/canada/saskatoon-health-region-apologizes-after-aboriginal-women-felt-pressured-by-staff-tohave-tubes-tied>.

32 Yvonne Boyer, "First Nations, Métis, and Inuit Women's Health" (March 2006) Discussion Paper Series in Aboriginal Health 4, National Aboriginal Health Organization \& Native Law Centre of Canada at 19. 
impact her physical and psychological health. Drawing on Statistics Canada census data, ${ }^{33}$ the Native Women's Association of Canada has compiled some basic statistics that draw a clear picture of the current health situation for Aboriginal women:

- Aboriginal women are four times more likely to disappear or meet a violent death than non-Aboriginal women.

- Aboriginal women can expect to live 76.8 years on average, versus 82 for nonAboriginal women.

- Among female youth, the rate of suicide deaths among registered Indians was nearly eight times that of other Canadian youth.

- The rate of suicide for Aboriginal women is three times the national average for non-Aboriginal women.

- Aboriginal women are almost three times more likely to contract AIDS than nonAboriginal women (23.1 percent versus 8.2 percent).

- Chronic conditions like arthritis, rheumatism, asthma, high blood pressure, gastrointestinal disorders, and cardiac conditions begin to affect Aboriginal women at 45 years of age.

- Seven percent of Aboriginal women over the age of 15 have been diagnosed with diabetes compared to 3 percent for the rest of the female population of this same age category.

- The demand for institutional and related continuing care needs for Aboriginal communities will continue to grow over the next few decades as a result of increases in the number of First Nation members aged 55 and over, and growing incidences of chronic disease. ${ }^{34}$

In addition:

- The rate of diabetes in Aboriginal women increases with age, with the result that 24 percent of Aboriginal women over the age of 65 have diabetes compared to 11 percent of the rest of the senior female population in Canada. ${ }^{35}$

- Sixty-seven percent of Aboriginal women are overweight versus 55 percent of nonAboriginal women. ${ }^{36}$

The health care of Aboriginal people falls under federal jurisdiction, and it follows that it is the Canadian government's responsibility to provide meaningful health care services to Aboriginal women. Health Canada's statistics confirm the alarming gap between the current health status of Aboriginal women in comparison with non-Aboriginal women.

Native Women's Association of Canada, Aboriginal Women: Statistics and Demographics (Ottawa: NWAC, 2009) [Aboriginal Women]; Native Women's Association of Canada, What Their Stories Tell Us: Research Findings from the Sisters in Spirit Initiative (Ottawa: NWAC, 2010), online: <www.nwac.ca/wp-content/ uploads/2015/07/2010-What-Their-Stories-Tell-Us-Research-Findings-SISInitiative.pdf $>$.

Aboriginal Women, ibid.

J Reading, The Crisis of Chronic Disease Among Aboriginal Peoples: A Challenge for Public Health, Population Health and Social Policy (Victoria: Centre for Aboriginal Health Research, 2009) at 83.

Marie Burke, "Aboriginal Women Considered to be Overweight," Saskatchewan Sage (February 2008) at 2,8 . 
This trend finds its roots in Canada's colonial history. The Indian Act, $1876^{37}$ was used as a tool to assimilate and colonize Aboriginal peoples and had the effect of annihilating Aboriginal women's societal place as a family anchor. When European settlers came to Canada, they brought with them an entirely different perspective on gender, and what women's role in society should be. In her article, "Colonialism and First Nations Women in Canada," Winona Stevenson explains the cultural differences between Indigenous and European women:

Where European women were fragile and weak, Aboriginal women were hard-working and strong; where European women were confined to affairs of the household, Aboriginal women were economically independent and actively involved in the public sphere; where European women were chaste and dependent on men, Aboriginal women had considerable personal autonomy and independence - they controlled their own sexuality, had the right to divorce, and owned the products of their labour. ${ }^{38}$

The colonialists did not want empowered Indigenous women and immediately set about creating laws that would subjugate and oppress these women. The Indian Act and An Act for the gradual enfranchisement of Indians are two examples of paternalistic Canadian federal laws that were enacted during the 1800 s for the purposes of assimilating Aboriginal people. ${ }^{39}$ Many of the provisions in the Indian Act, 1876 removed women's rights and entitlements such as the ability to vote for the election of band chiefs, and created the loss of her band membership upon marriage to an Indian of another band or a non-treaty Indian. ${ }^{40}$ It wasn't until 1951 that Aboriginal women were allowed to participate in band elections or band meetings. ${ }^{41}$

Instead of their Aboriginal traditional leadership systems, which included women in the decision-making process, Indigenous women were forced to submit to the band council structure (which had exclusionary membership rules). The Indian Act, 1876 introduced the legal concept of "Status Indian," which carries the requirement that status follow in the male line, thereby excluding many women from membership within their own communities. Loss of membership to their community was devastating for Aboriginal women, as this meant a loss of their cultural, familial, historical, and emotional ties.

In addition to excluding women from their own communities, Canadian laws have served to legally silence Indigenous women. After the enactment of the Indian Act, 1876 and An Act for the Gradual Enfranchisement of Indians, politics was participated in by men only. Male band members voted for the chiefs, and the traditional consensus-based decision model was replaced with a hierarchical band council system. ${ }^{42}$

\section{SC 1876.}

Winona Stevenson, "Colonialism and First Nations Women in Canada" in Enakshi Dua \& Angela Robertson, eds, Scratching the Surface: Canadian Anti-Racist, Feminist Thought (Toronto: Women's Press, 1999) 49 at 56.

39 Indian Act, 1876, supra note 37, s 8; An Act for the gradual enfranchisement of Indians, the better management of Indian affairs, and to extend the provisions of the Act 31st, Victoria, Chapter 42, SC 1869, c 6 [An Act for the gradual enfranchisement of Indians].

$40 \quad$ Indian Act, 1876, ibid, ss 61, 3(3)(d).

$41 \quad$ Kerri A Froc, "Multidimensionality and the Matrix: Identifying Charter Violations in Cases of Complex Subordination" (2010) 25:1 CJLS 21 at 30-31. Ibid. 
These European laws unravelled thousands of years of equality between women and men, and had a devastating impact on Aboriginal women. Over time, Aboriginal men began to develop business relationships with European men through a variety of political and economic transactions. ${ }^{43}$ Due to the ways the European colonialists functioned, operating from a male dominated perspective became the norm. Aboriginal men were given all the power within their communities as a strong male chiefly authority emerged through colonial influence. As a result of this societal shift from egalitarian gender roles to a patriarchal structure, Aboriginal women began to lose respect from men within their communities. Many Indigenous men's minds had been shaped with the thoughts and beliefs of the settlers. Evidence of this attitude of supremacy over Aboriginal women is often seen today as indicated by the high rates of violent domestic abuse.

\section{A. Residential Schools}

Residential schools were one of the clearest manifestations of colonialism in Canada. A product of the Indian Act, 1876, which allowed the Federal Minister of Indian Affairs to control education for Indians, the residential school experience entailed a separation of Aboriginal children from their family members. Parents were not allowed to visit their children in residential schools. ${ }^{44}$ If children were allowed to return home at all, they were only sent home for two months of the year. ${ }^{45}$ Parents lost parenting skills and children forgot how to live in a family - the family unit was broken. Within residential schools, insufficient health care facilities, inadequate diets, and poor sanitation contributed to the spread of disease, suffering, and death of students. ${ }^{46}$ Among the most widespread and deadly illnesses was tuberculosis, which ultimately reached epidemic levels. ${ }^{47}$ Malnourishment and even starvation were common, and physical, mental, and sexual abuse was rampant. ${ }^{48}$ The longterm effects of the residential school experience on the physical and mental health of Aboriginal people continue to this day.

$43 \quad$ Stevenson, supra note 38 at 63.

44 The Truth and Reconciliation Commission of Canada, Honouring the Truth, Reconciling for the Future: Summary of the Final Report of the Truth and Reconciliation Commission of Canada (Winnipeg: TRC, 2015), online: < publications.gc.ca/collections/collection_2015/trc/IR4-7-2015-eng.pdf > [Honouring the Truth].

$45 \quad$ Yvonne Boyer, "First Nations Women's Contributions to Culture and Community Through Canadian Law," in Gail Guthrie Valaskakis, Madeleine Dion Stout \& Eric Guimond, eds, Restoring Balance: First Nations Women, Community, and Culture (Winnipeg: University of Manitoba Press, 2009) 69 at 90 :

At one time, there were eighty-eight schools operating in Canada. Although the Government of Canada officially withdrew in 1969, a few of the schools continued operating throughout the 1960s, 1970s, and 1980s. Akaitcho Hall in Yellowknife did not close until the 1990s. These schools were run through a partnership between the federal government and the churches. An estimated 100,000 to 150,000 First Nation, Métis, and Inuit children attended residential schools.

Thousands of former students have come forward to claim that physical, emotional, and sexual abuse were rampant in the school system and that little was ever done to stop it or to punish the abusers.

46 See e.g. Cheryle Partridge, "Residential Schools: The Intergenerational Impacts on Aboriginal Peoples" (2010) 7 Native Social Work J 33. See also RG Ferguson, Studies in Tuberculosis (Toronto: University of Toronto Press, 1955) at 6, cited in G Graham-Cumming, "Health of the Original Canadians: 1867-1967" (1967) 23:2 Medical Service J 115 at 134.

47 PH Bryce, The Story of a National Crime: Being a Record of the Health Conditions of the Indians of Canada from 1904 to1921 (Ottawa: James Hope and Sons, 1922), cited in Maureen K Lux, Medicine That Walks: Disease, Medicine, and Canadian Plains Native Peoples: 1880-1940 (Toronto: University of Toronto Press, 2001) at 192 (regarding the health of the pupils, the report states that 24 percent of all the pupils who had been in the schools were known to be dead, while at one school on the File Hills reserve, which gave a complete return, to date 75 percent were dead at the end of the 16 years since the school opened). 
One of the most destructive impacts of the residential schools was depriving Aboriginal women of their traditional roles as mothers, daughters, grandmothers, aunts, and caregivers. In Aboriginal society, women are critical in determining the health of their community and are the primary caregivers of children, families, and the elderly, often delivering health care services to family and community members. As a result of residential schools, the emotional bond between mothers and daughters was severed, resulting in generations of young Aboriginal women growing up without learning about their role as caregivers and healers.

The denigration of Aboriginal women's roles in contemporary Canadian society is due to the impact of colonization and, as a result, "the cultural and social degradation of Aboriginal women has been devastating." 49 The annihilation of the family unit, including through residential schools, has resulted in loss of cultural identity, marginalization, and a diminished health status that falls well below the norm for mainstream Canadians.

\section{B. Truth AND Reconciliation Calls to ACtion}

From June 2008 to December 2015, the Truth and Reconciliation Commission of Canada was gathered together as a response to the charges of abuse and other harmful impacts caused by the residential school legacy. In their report, the Commission made a total of 94 calls to action, seven of which were focused entirely upon improving of health care services for Aboriginal people in Canada. Amongst the seven health-related recommendations, Recommendation 18 calls upon the federal, provincial, and territorial governments to acknowledge that the current state of Aboriginal health in Canada is a direct result of Canadian government policies. ${ }^{50}$ Recommendation 19 requests that the Canadian government close the gaps in health outcomes between non-Aboriginal and Aboriginal communities. ${ }^{51}$ Call to Action 41 directly addresses the issue of the disproportionate victimization of Aboriginal women and girls. The Commission also requests that the government conduct an inquiry to investigate the epidemic of missing and murdered Aboriginal women and children and its direct correlation with the residential school legacy. ${ }^{52}$

\section{A Rights-Based ApProach to Health}

A rights-based approach that addresses inequities and discriminatory practices is critical when examining a right to health. The notion of an inherent right comes from the "perception of the inherent dignity of every human being." ${ }^{, 3}$ The preamble of the Universal Declaration of Human Rights provides further clarity on the definition of a right, when it speaks about, "the recognition of the inherent dignity of the equal and inalienable rights of all members of the human family." 54 Viewing health as an inherent right encourages participation of

\footnotetext{
49 The Aboriginal Justice Implementation Commission, "The Justice System and Aboriginal People," online: <www.ajic.mb.ca/volumel/chapter13.html\#2>.

Truth and Reconciliation Commission of Canada, Truth and Reconciliation Commission of Canada: Calls to Action (Winnipeg: TRC, 2015) at 2.

Ibid at $2-3$.

Ibid at 4.

Virginia A Leary, "The Right to Health in International Human Rights Law" (1994) 1:1 Health \& Human Rights 24 at 36.

GA Res 217A (III), UNGAOR, 3rd Sess, Supp No 13, UN Doc A/810 (1948) 71 [UDHR].
} 
individuals and groups affected by particular laws and regulations that might be infringing on their health.

Distinguished legal scholar Virginia Leary states that there are many international instruments and agreements that recognize this right, although the specific "right to health" language varies. ${ }^{55}$ For instance, the World Health Organization's Declaration of Alma-Ata provides that " $[\mathrm{t}]$ he people have the right and duty to participate individually and collectively in the planning and implementation of their health care. ${ }^{, 56}$ Leary notes that human rights and health care are intertwined: "Participation of individuals and groups in matters that affect them is essential to the protection of all human rights." ${ }^{57}$ Not only is the principle of equality critical to understanding the rights perspective in the context of international law, but equal treatment is also the fundamental basis of all human rights.

Canada, as a signatory to a number of international treaties and covenants, has acknowledged its international obligations toward Aboriginal peoples in Canada. These (and other instruments) provide the human rights standards that bind all Canadians, including the Aboriginal population. ${ }^{58}$

The right to health is widely recognized under international law, including in a number of international human rights treaties ratified by Canada. For instance, Article 12 of the International Covenant on Economic, Social and Cultural Rights recognizes "the right of everyone to the enjoyment of the highest attainable standard of physical and mental health." Article 10 of the Additional Protocol of the American Convention on Human Rights in the Area of Economic, Social and Cultural Rights "Protocol of San Salvador" states that "(1) Everyone shall have the right to health, understood to mean the enjoyment of the highest level of physical, mental and social well-being. (2) In order to ensure the exercise of the right to health, the State Parties agree to recognize health as a public good." 60 Article XI of the American Declaration of the Rights and Duties of Man provides: "Every person has the right to the preservation of his health through sanitary and social measures relating to food, clothing, housing and medical care." ${ }^{, 1}$

Similarly, a right to non-discrimination in relation to health is identified in several international instruments. The WHO describes these non-discrimination requirements in the following terms:

Leary, supra note 53. See also Hernan L Fuenzalida-Puelma \& Susan Scholle Connor, eds, The Right to Health in the Americas: A Comparative Constitutional Study (Washington: PAHO, 1989) at 596-600. The Pan American Health Organization (PAHO), while using the phrase 'right to health' suggests that the term "may be incomplete and conceptually misleading." PAHO suggests it would be more correct to view this right as a "right to health protection," which itself is comprised of two rights - the right to health care and the right to healthy conditions.

56 World Health Organization, Declaration of Alma-Ata (Copenhagen: WHO Regional Office for Europe, 1978), art 4.

$57 \quad$ Leary, supra note 53 at 38 .

58 See S James Anaya, Richard Falk \& Donat Pharand, Canada's Fiduciary Obligation to Aboriginal Peoples in the Context of Accession to Sovereignty by Quebec, vol 1 (Ottawa: Minister of Supply and Services, 1995).

59 16 December 1966, 993 UNTS 3 art 12, 6 ILM 368 (entered into force 3 January 1976) [ICESR].

6017 November 1988, OASTS 6 art 10, 28 ILM 156 (entered into force 16 November 1999).

612 May 1948, OASTS 36 art XI (entered into force 18 July 1978). 
In relation to health and health-care the grounds for non-discrimination have evolved and can now be summarized as proscribing "any discrimination in access to health care and the underlying determinants of health, as well as to means and entitlements for their procurement, on the grounds of race, colour, sex, language, religion, political or other opinion, national or social origin, property, birth, physical or mental disability, health status (including HIV/AIDS), sexual orientation, civil, political, social or other status, which has the intention or effect of nullifying or impairing the equal enjoyment or exercise of the right to health."62

The non-discrimination requirements referred to by the WHO are reflected in Article 5(e)(iv) of the International Convention on the Elimination of All Forms of Racial Discrimination, which states that "States Parties undertake to prohibit and to eliminate racial discrimination ... in the enjoyment of ... [t] he right to public health, medical care, social security and social services." ${ }^{63}$ Article 11(1)(f) of the Convention on the Elimination of All Forms of Discrimination against Women refers to women's health and non-discrimination, stating that "States Parties shall take all appropriate measures to eliminate discrimination against women ... in particular ... [t] he right to protection of health and to safety in working conditions, including the safeguarding of the function of reproduction." ${ }^{64}$ The CEDAW also confirms that adequate maternal and child health care is a matter of human rights. ${ }^{65}$

Aboriginal women's health is comprised of rights that are dependent on other rights for strength, support, and fulfillment — they are, like other fundamental human rights, interconnected. In 1993, at the World Conference on Human Rights in Vienna, the following declaration was made:

\begin{abstract}
All human rights are universal, indivisible and interdependent and interrelated. The international community must treat human rights globally in a fair and equal manner, on the same footing, and with the same emphasis. While the significance of national and regional particularities and various historical, cultural and religious backgrounds must be borne in mind, it is the duty of States, regardless of their political, economic and cultural systems, to promote and protect all human rights and fundamental freedoms. ${ }^{66}$
\end{abstract}

International health law scholar Virginia Leary suggests that "the right to health cannot be effectively protected without respect for other recognized rights." ${ }^{67}$ Human rights activist Jonathan Mann elaborates:

The central idea of the health and human rights movement is that health and human rights act in synergy. Promoting and protecting health requires explicit and concrete efforts to promote and protect human rights and dignity, and greater fulfillment of human rights necessitates sound attention to health and to its societal determinants. $^{68}$

World Health Organization, "25 Questions \& Answers on Health \& Human Rights" (July 2002) 1 Health \& Human Rights Publication Series at 13.

21 December 1965, 660 UNTS 195 art 5(e)(iv) (entered into force 4 January 1969) [CERD].

18 December 1979, 1249 UNTS 13 art 11(1)(f), 19 ILM 33 (entered into force 3 September 1981) [CEDAW].

Ibid, art 12(2).

World Conference on Human Rights, Vienna Declaration and Programme of Action, UN Doc A/CONF.157/23 (1993), art 5, 32 ILM 1661 [Vienna Declaration].

Leary, supra note 53 at 39 .

Jonathan M Mann et al, eds, Health and Human Rights: A Reader (New York: Routledge, 1999) at 5. 
The health and human rights movement has clearly recognized and affirmed that "[a] human rights perspective requires a view of health that takes seriously its connections to social conditions such as poverty and discrimination." ${ }^{, 69}$ Similarly, "[w]hen health is understood to include physical, mental, and social well-being, it seems reasonable that the violation of any human right would impact adversely on health." ${ }^{, 70}$ Further, human rights are both interdependent and inextricably linked to the right to a healthy environment. "Health is a fundamental human right indispensable for the exercise of other human rights," which include, among others, the right to food; the right to adequate housing; the right to education; the right to work and rights at work; the right to life; the right to information; the right to physical integrity; the right to be free from discrimination on any ground, including gender, race, religion, sexual orientation, and disability; and the right to self-determination. ${ }^{71}$ These concepts are critical when addressing Aboriginal women's health issues and their connection to poverty.

International law finds its source in state-to-state agreements and through the formal constitutional procedures and practices of individual states. These practices are shaped by a sense of moral and social obligation and, over time, acquire the status of customary international law. ${ }^{72}$ Often these customary norms are derived from non-obligatory international instruments such as "declarations" or resolutions of the UN General Assembly and other international bodies. Two of the most important applicable examples are the $U D H R^{73}$ and the United Nations Declaration on the Rights of Indigenous People. ${ }^{74}$ A review of each Declaration follows.

\section{A. UNIVERSAL DECLARATION OF HUMAN RIGHTS}

The UDHR is among the first of many international agreements to outline and define human rights. The United Nations saw a need to articulate the term "human rights" as outlined in the 1945 Charter of the United Nations. ${ }^{75}$ The UDHR refers to "the dignity and worth of the human person and the equal rights of men and women." ${ }^{, 76}$ First Nation Elders, leaders, and organizations saw the $U D H R$ as a critical tool for decolonizing Indigenous

Lynn P Freedman, "Censorship and Manipulation of Family Planning Information: An Issue of Human Rights and Women's Health" in Mann et al, ibid at 151.

Mann et al, ibid at 73.

CESCR General Comment No 14: (2000) The Right to the Highest Attainable Standard of Health, UNCECSCR, 22nd Sess, UN Doc E/C.12/2000/4 (2000) at paras 1, 30-45 [UNCESCR]. See also The Iowa City Appeal in Advancing the Human Right to Health, adopted 22 April 2001 by the Global Assembly on Advancing the Human Right to Health, convened at the University of Iowa, Iowa City, Iowa, 20-22 April 2001, at 3 (prior to all other treaties and conventions, the UDHR advanced the international recognition of the interdependence and indivisibility of human rights). See also González, supra note 2 (the author states that Article 25 of the declaration emphasizes recognition of the right of all persons to an adequate standard of living, including guarantees for health and well-being. It acknowledges the relationship between health and well-being and its links with other rights, such as the right to food and the right to housing, as well as medical and social services. It adopts a broad view of the right to health as a human right, although health is but one component of an adequate standard of living).

Anaya, Falk \& Pharand, supra note 58 at 2.

UDHR, supra note 54.

United Nations Declaration on the Rights of Indigenous People, GA Res 61/295, UNGAOR, 61 st Sess, Sup No 49, UN Doc A/61/53 (2007), art 24(1) [UNDRIP].

26 June 1945, Can TS 1945 No 7, art 1, paras 1-3; art 55 [UN Charter].

UDHR, supra note 54, Preamble. 
peoples as it affirmed human rights in international law. ${ }^{77}$ Professor Sa'ke'j Youngblood Henderson notes:

\begin{abstract}
Along with the Universal Declaration, other declarations have reformed the customary law of the colonial era and generated post colonial customary law, conventional law, and pre-emptory norms in international law. As well, the General Assembly of the UN, by binding conventions and multilateral treaties, sustained an international consensus that moved the inherent rights of humans into an internationally protected code of human rights, one to which all nations can subscribe and to which all people can aspire. ${ }^{78}$
\end{abstract}

The UDHR contains 30 articles, and each one details the freedoms that people are guaranteed simply by virtue of being human. It is prefaced by a preamble that includes the statement: "the inherent dignity and the equal and inalienable rights of all members of the human family is the foundation of freedom, justice and peace in the world."79 The name of the document is a direct reflection that it applies to all people (including Indigenous people).

The UDHR provides a critical framework for implementing a rights-based approach to Aboriginal women's health by recognizing the dignity and worth of the human person and the equal rights of men and women. As this declaration confirms the inherent rights of Aboriginal women, it may be used, in combination with the UNDRIP and domestic laws, to advance the right to health through the use of this internationally protected code of human rights.

\title{
B. UNITED NATIONS DECLARATION oN THE RIGHTS OF INDIGENOUS PEOPLES
}

Of particular significance to Aboriginal women's right to health is UNDRIP. On 13 September 2007, 370 million Indigenous people in 70 countries applauded the adoption of the UNDRIP, which promises to provide a just legal framework for "achieving reconciliation, redress and respect." ${ }^{\prime 80}$ The vote at the United Nations General Assembly was 144 states in favour of the adoption of the UNDRIP and four opposed, including Canada, the United States, New Zealand, and Australia. ${ }^{81}$ Although Canada was involved in the 22-year drafting process, it did not sign the UNDRIP. ${ }^{82}$ In defending its failure to sign, Canada stated that the UNDRIP "might not fully accord with the norms and precedents that have been established through judicial decisions and negotiations on land claims and self-government." affirmed that its decision to oppose the UNDRIP was the "right one" and that it had "principled and well-publicized concerns," ${ }^{\prime 5}$ while dealing with Indigenous issues "openly,

James (Sa'ke'j) Youngblood Henderson, Indigenous Diplomacy and the Rights of Peoples: Achieving UN Recognition (Saskatoon: Purich Publishing, 2008) at 15.

Ibid at 30 .

UDHR, supra note 54 .

Jackie Hartley, Paul Joffe \& Jennifer Preston, Realizing the UN Declaration on the Rights of Indigenous Peoples: Triumph, Hope, and Action (Saskatoon: Purich Publishing, 2007) at 12. Ibid at 13.

See Canadian Human Rights Commission, "Raising Awareness. Influencing Positive Change” (Ottawa: Minister of Public Works and Government Services, 2010).

Ibid.

Letter from Minister of Indian Affairs and Northern Development, Chuck Strahl, to Assembly of First Nations National Chief Phil Fontaine (10 December 2007), cited in Hartley, Joffe \& Preston, supra note 80 at 71.

Ibid. 
honestly and with respect." ${ }^{, 86}$ Contrary to international legal precedent, Canada claimed "[a] declaration is not legally binding ... [d] eclarations only represent political commitment from the states that vote in favour of adopting them." 87

However, on 3 March 2010, the Speech from the Throne stated that the Government of Canada would now endorse the UNDRIP in a manner consistent with Canada's Constitution and laws. ${ }^{88}$ On 12 November 2010, Prime Minister Stephen Harper issued a statement indicating Canada's support for the $U N D R I P^{89}$ as follows:

[A]fter careful and thoughtful consideration, Canada has concluded that it is better to endorse the UNDRIP while explaining its concerns, rather than simply rejecting the overall document.

Although the UNDRIP does not reflect customary international law or change Canadian laws, Canada believes that the UNDRIP has the potential to contribute positively to the promotion and respect of the rights of indigenous peoples around the world..$^{90}$

On this basis, Canada has committed to respect the international human rights principles contained in the UNDRIP domestically, and to deal with the Indigenous peoples in Canada with principles of equality, partnership, good faith, and mutual respect.

Article 21.1 of the UNDRIP states: "Indigenous peoples have the right, without discrimination, to the improvement of their economic and social conditions, including, inter alia, in the areas of education, employment, vocational training and retraining, housing, sanitation, health and social security."

Article 24 states that:

1. Indigenous peoples have the right to their traditional medicines and to maintain their health practices, including the conservation of their vital medicinal plants, animals and minerals. Indigenous individuals also have the right to access, without any discrimination, to all social and health services.

2. Indigenous individuals have an equal right to the enjoyment of the highest attainable standard of physical and mental health. States shall take the necessary steps with a view to achieving progressively the full realization of this right.

Chuck Strahl, "Address" (Delivered at Luncheon Hosted by Canada's Permanent Mission to the United Nations, New York, 1 May 2008), cited in Hartley, Joffe \& Preston, supra note 80 at 71.

87 Indigenous and Northern Affairs Canada, "United Nations Declaration on the Rights of Indigenous Peoples," online: <https://www.aadnc-aandc.gc.ca/eng/1309374407406/1309374458958?pedisable= true $>$ [INAC, "UNDRIP”]. See Claire Charters \& Rodolfo Stavenhagen, eds, Making the Declaration Work: The United Nations Declaration on the Rights of Indigenous Peoples (Copenhagen: International Working Group for Indigenous Affairs, 2009) at 13. See also Anaya, Falk \& Pharand, supra note 58; Hartley, Joffe \& Preston, supra note 80.

Canada, Governor General, A Stranger Canada, A Stranger Economy. Now and for the Future, Speech from the Throne (3 March 2010) at 19.

89 CBC News, "Canada Endorses Indigenous Rights Declaration,” CBC News (12 November 2010), online: $<$ www.cbc.ca/news/canada/canada-endorses-indigenous-rights-declaration-1.964779>. 
The UNDRIP thus provides an important new framework for a rights-based approach to Aboriginal Women's health, recognizing the right to health both as a self-standing right and a right that is interdependent with many other rights, including the rights to equality and to the improvement of economic and social conditions.

\section{The Constitution, Aboriginal Rights, AND EQUALITY GUARANTEES}

The Supreme Court of Canada has declared that "where the text of the domestic law lends itself to it, one should also strive to expound an interpretation which is consonant with the relevant international obligations." 91 This is especially important for Aboriginal women's health and the application of international standards. Legal scholar, Patrick Macklem suggests that: "[a]s with constitutional law, international law is not a static body of manifest legal rules but an active, evolving, and interpretive inquiry into both what the law is and what it ought to become." 92

A constitution has been described as "a mirror reflecting the national soul" 93 that must recognize and protect the values of a nation. ${ }^{94}$ To ensure the values of the nation are appropriately protected, the Constitution has legal supremacy over all laws. ${ }^{95}$ In addition to legal supremacy, our Constitution is a melding and merging of earlier philosophies and legal developments under the original British North America Act. ${ }^{96}$ Upon the entrenchment of section 35 in the Constitution Act, 1982, Aboriginal and treaty rights were explicitly recognized and included in Canada's new constitutional regime. That is, the original constitutional documents that created Canada as a legal entity, coupled with the 1982 amendments (and in particular, section 35), ${ }^{97}$ extended constitutional protection and the rule of law to Aboriginal people. ${ }^{98}$ Section $35(1)$ reads " $[\mathrm{t}]$ he existing aboriginal and treaty rights of the aboriginal peoples of Canada are hereby recognized and affirmed." 99

Section 35(1) of the Constitution Act 1982 accorded constitutional status to "existing" Aboriginal and treaty rights. For the purpose of section 35(1), these rights refer to those that were not extinguished before 17 April 1982. Prior to 1982, Aboriginal rights did exist and were recognized under common law. They did not have constitutional status, and Parliament could extinguish or regulate those rights at any time. However, the Supreme Court has confirmed that the regulation of an Aboriginal activity by specific imperial treaty, act, or legislation does not amount to its extinguishment, and the Court has affirmed the continuity of an Aboriginal right and the government obligations to protect Aboriginal rights through section 35 of the Constitution Act.

National Corn Growers Assn v Canada (Import Tribunal), [1990] 2 SCR 1324 at para 74. Patrick Macklem, Indigenous Difference and the Constitution of Canada (Toronto: University of Toronto Press, 2001) at 36.

RI Cheffins \& RN Tucker, The Constitutional Process in Canada, 2nd ed (Toronto: McGraw-Hill Ryerson, 1976) at 4, cited in Peter W Hogg, Constitutional Law of Canada, 4th ed (Scarborough: Carswell, 2002) at 1-1.

Hogg, ibid.

Constitution Act, 1982, supra note 3.

Ibid.

Ibid.

Marie Battiste \& James (Sa'ke'j) Youngblood Henderson, Protecting Indigenous Knowledge and Heritage: A Global Challenge (Saskatoon: Purich Publishing, 2000) at 205.

Constitution Act, 1982, supra note 3, s 35(1). 
The rights captured within section 35 , and read through a constitutional supremacy framework, provide an important structure for understanding equality rights (and therefore health rights) for Aboriginal women, both within the context of section 15 of the Canadian Charter of Rights and Freedoms (Charter) and within section 35(4) of the Constitution Act, 1982, which states that "[n] otwithstanding any other provision of this Act, the aboriginal and treaty rights referred to in subsection (1) are guaranteed equally to male and female persons. $" 100$ In addition to the protection of individual equality rights under section 15 of the Charter, the rights referred to in section 35(4) encompass the collective rights of Aboriginal society as a whole within the bundle of Aboriginal rights. ${ }^{101}$

The equality guarantees in section 35(4) have rarely been used to advance the equality rights of Aboriginal women. ${ }^{102}$ Often the rights to gender equality that Aboriginal people collectively possess are viewed as non-existent, created by statute, or 'given' to Aboriginal women post-contact. This analysis displaces the issue from the Aboriginal context and transforms it into one of Charter application. The underlying message is that Aboriginal women do not have Aboriginal rights to equal treatment that include equal rights to health. This type of analysis is neither correct nor useful when examining equality rights for Aboriginal women recognized in section 35(4).

\section{A. Aboriginal Women's Equality Rights as Individuals}

Aboriginal people in Canada not only possess section 35 rights, individually and collectively, but they also possess the individual rights set out in the Charter, which include the right to vote, the right to life, liberty, and security of the person, equality rights, ${ }^{103}$ legal rights of persons accused of crimes, language rights, and protection of multicultural heritages, among others. The section 7 "right to life" provides the most fundamental rights guaranteed for Aboriginal women. In cases where Aboriginal women have been deprived of life, or where their life has been damaged (in particular through harm to their health status), the advancement of Charter arguments and rights claims may be useful.

It is important to note that the equality provisions in section 15 of the Charter do not invalidate Aboriginal or treaty rights. ${ }^{104}$ In 1985, when section 15 of the Charter came into

100 Constitution Act, 1982, supra note 3, s 35(4).

$101 \quad$ Battiste \& Henderson, supra note 98 at $65-72$

102 See Doug Sanders, "The FMCs: What Was Offered?" (1983), online: Saskatchewan Indian Cultural College <www.sicc.sk.ca/archive/saskindian/a87sum30.htm>. Interestingly, lawyer Doug Sanders commented on what section 35(4) means:

Section 35(4) was added guaranteeing treaty and aboriginal rights equally to men and women. This provision was supposed to end the sexual discrimination in the Indian Act, but it was written by the lawyers from the Department of Justice in such a way that it is not aimed at rights under legislation. No one knows what the section means.

See McIvor v The Registrar, Indian and Northern Affairs Canada, 2007 BCSC 827 and 2007 BCSC 1732, rev'd in part 2009 BCCA 153, leave to appeal to SCC refused, 33201 (5 November 2009).

103 Canadian Charter of Rights and Freedoms, s 15, Part I of the Constitution Act, 1982, being Schedule $\mathrm{B}$ to the Canada Act 1982 (UK), 1982, c 11 ("[n] otwithstanding anything in this Charter, the rights and freedoms referred to in it are guaranteed equally to male and female persons").

Hogg, supra note 93 at 27-35. Hogg explains the advantages that section 35 rights possess by being situated outside of the Charter rights. For instance, section 35 is not subject to section 1 of the Charter, it is not subject to legislative override through section 33, nor are the rights effective only against government action through section 32 (ibid). Because section 35 is outside of the Charter provisions, these rights are not enforceable through section 24 of the Charter. Section 25 of the Charter, supra note 103 further provides that the Charter must not "derogate from any aboriginal, treaty or other rights or freedoms that pertain to the aboriginal peoples of Canada." 
effect, the concept of equality articulated through the provisions in section 15 was that the effect of the law would be to give substantive equality to all members of a group (including Aboriginal women). Establishing the concepts of equality and nondiscrimination that underlie section 15 of the Charter requires an approach that focuses on the effects of a law on those affected by a distinction that were affirmed by unanimous judgments under the Supreme Court Chief Justice Dickson in 1989. These concepts were upheld in later judgments with respect to the same principle of substantive equality (equality of result), not just formal equality (equality of treatment). The notion of formal equality (equal treatment) was rejected. ${ }^{105}$ This is important because it affirms that the issue of equality should not be construed in the Eurocentric, feminist, or western legal tradition understandings of "balance" as meaning "equality" or "equal treatment." Aboriginal law is not ordered around Eurocentric values or perceptions of what is balanced or equal. Rather, for Aboriginal women, balance is understood as respecting the laws and relationships that Aboriginal women have in Aboriginal society and the ecological order of the universe.

\section{B. Aboriginal Women's Collective Equality Rights}

The focus of section 35(4) is the equal application of Aboriginal and treaty rights to both males and females. These rights are collective and were specifically and intentionally enacted to address the whole of Aboriginal and treaty rights enshrined in section 35 . When assessing whether an activity is an Aboriginal right, the courts use certain criteria and principles of interpretation to assist in this understanding.

Aboriginal rights are sui generis in nature. ${ }^{106}$ The Supreme Court of Canada has long recognized the unique nature of Aboriginal rights as not being recognizable within the common law, ${ }^{107}$ and has therefore described them as a unique class of rights. ${ }^{108}$ The sui generis concept is employed to discard those notions of the common law that have not been "sensitive to the aboriginal perspective itself on the meaning of the rights at stake." 109 As such, the doctrine can be characterized as a part of the common law that attempts to leave behind much of the common law. ${ }^{110}$

Noting that the sui generis nature of Aboriginal rights demands a unique approach to the treatment of evidence, which accords due weight to the perspective of Aboriginal peoples, the Supreme Court of Canada in $R v$ Van der Peet developed a test to identify an existing Aboriginal right within the meaning of section $35 .{ }^{111}$ In order for an activity to be an Aboriginal right, the activity must be a practice, custom, or tradition integral to the

See Benoit v Canada, 2002 FTC 243, [2002] 2 CNLR 1 at para 366; Lovelace v Ontario, 2000 SCC 37, [2000] 1 SCR 950 at para 60. See also Corbiere v Canada (Minister of Indian and Northern Affairs), [1999] 2 SCR 203 at para 94.

Blacks Law Dictionary, 7th ed, sub verbo "sui generis" cited in J Woodward, Native Law (Toronto: Carswell, 2002) at 5-7 (rights that are sui generis do not fit into categories of French or English law). See e.g., Blueberry River Indian Band v Canada (Department of Indian Affairs and Northern Development), [1995] 4 SCR 344; Guerin v The Queen, [1984] 2 SCR 335; Delgamuukw v British Columbia, [1997] 3 SCR 1010 [Delgamuukw].

John Borrows, "Frozen Rights in Canada: Constitutional Interpretation and the Trickster" (1997) 22:1 Am Indian L Rev 37.

$R \vee$ Sparrow, [1990] 1 SCR 1075 at 1112 [Sparrow].

John Borrows \& Leonard I Rotman, "The Sui Generis Nature of Aboriginal Rights: Does It Make a Difference?" (1997) 36:1 Alta L Rev 9 at 26-27.

[1996] 2 SCR 507 [Van der Peet]. 
distinctive culture of the Aboriginal group asserting that right. In order for a practice to be integral, it must have been of "central significance" to the society, must be a defining characteristic, and "one of the things which made the culture of the society distinctive."112 The practices, customs, and traditions that constitute Aboriginal rights are those that can be rooted in pre-contact Aboriginal communities. ${ }^{113}$ In the Court's view, practices that developed "solely as a response to European influences" do not qualify as an Aboriginal right. ${ }^{114}$ The existence of the right has to be specific to a definable Aboriginal group, and the right at issue must be distinctive in relation to that society. ${ }^{115}$ It is important to note that the Van der Peet test, which the courts use to determine whether Aboriginal rights exist, is based on male gendered activities (hunting and fishing) in specific locations. In this context, the Courts are looking for specific rights attached to these activities.

Professor Brian Slattery provides an analysis of the rights examined in Van der Peet as generic rights, which should be applied generally. Using Slattery's analysis, the Van der Peet test may be applied when examining gender balance as an Aboriginal right within the sphere of generic Aboriginal rights. Slattery explains:

\begin{abstract}
A generic aboriginal right is a right of a standardized character held by all aboriginal groups that satisfy certain criteria. The basic contours of a generic right are determined by general principles of law rather than aboriginal practices, customs and traditions. So the broad dimensions of the right are identical in all groups where the right arises, even if certain concrete features of the right may vary somewhat from group to group. $^{116}$
\end{abstract}

Generic rights are those which Aboriginal peoples use to conclude treaties with the Crown, to maintain and write their own laws and customs, and the generic right to selfgovernment. ${ }^{117}$ Upon closer examination, Professor Slattery concludes that the right recognized by the Supreme Court in Van der Peet is not so much a specific right as it is, in fact, a generic right, recognizing that an Aboriginal group has the right to engage in practices that are based on customs and traditions that formed a central and significant part of its ancestral culture. The generic right, then, gives rise to a series of specific rights that differ from group to group and that must be proved individually. The generic right is a right of "uniform dimensions, held by all aboriginal groups." 118 The basic contours of generic Aboriginal rights are established by the common law. At the abstract level, these rights are uniform and do not vary from group to group. Nevertheless, at the concrete level, generic rights may assume a range of particular forms that vary from group to group, in accordance with their distinctive histories, cultures, and preferences. ${ }^{119}$

116 Brian Slattery, "Making Sense of Aboriginal and Treaty Rights" (2000) 79:2 Can Bar Rev 196 at 211. See also Sawridge Band v Canada, [2006] 1 CNLR 292 at paras 285-99 (however, in this case, Justice Russell cautions that Slattery's analysis of claims to self-government under section 35(1) may not be understood as a generic right in relation to the right to self-government). 
The generic rights test in Van der Peet, which determines that Aboriginal rights must be adjudicated on a general basis, is useful in relation to Aboriginal peoples in the context of gender balanced activities. Accordingly, the appropriate question becomes what generic rights are available for issues of Aboriginal women's health? To answer this question, the historical development of Aboriginal rights provides a framework for the analysis of Aboriginal women's right to health.

\section{ABORIGINAL RightS FRAMEWORK}

The legal concept of Aboriginal rights rests on the recognition that when Europeans arrived in North America, Aboriginal peoples were already there. As early as 1832, in Worcester v. State of Georgia, ${ }^{120}$ the Chief Justice of the United States Supreme Court commented that the origins of Aboriginal claims to land and their right to self-governance lay in the relationship that evolved between Aboriginal people's pre-existing rights as "ancient possessors" of North America and the assertion of sovereignty by European nations. This finding, that Aboriginal societies were here first and have unique rights, has been quoted with approval by the Supreme Court of Canada. In Calder v. British Columbia (Attorney General), Justice Judson noted "the fact is that when settlers came, the Indians were there, organized in societies and occupying the land as their forefathers had done for centuries. This is what Indian title means." ${ }^{121}$ It is this prior occupancy by Aboriginal peoples, then, which is the foundation of Aboriginal rights. ${ }^{122}$ As a result, the existence of Aboriginal rights is not dependent upon treaties or Crown grants, ${ }^{123}$ presumed grant or prescription, ${ }^{124}$ or on legislative enactments, executive orders, or judicial declarations. ${ }^{125}$ Rather, Aboriginal rights are based on the historic occupation and use of ancestral lands by Aboriginal peoples. ${ }^{126}$ The source of these Aboriginal rights resides in, or is derived from, Aboriginal knowledge, language, and laws. ${ }^{127}$ One of the most significant historical uses of the land in Aboriginal communities was its use for health and medicinal purposes. Indigenous people viewed healing as a holistic process, a process similar to the cycle they saw occurring in nature where all things are connected. Gender balance was a characteristic of early Aboriginal society.

From this holistic outlook, healing methods were developed that reflected the diversity of Indigenous cultures. Herbs, plants, and ceremonial dances were, and still are, some of the elements involved in their traditional healing practices. Many accounts from explorers, Jesuit

31 US $515(1832)$ at 542-43, 559. See also Van der Peet, supra note 111 at para 30.

[1973] SCR 313 at 328. See also Roberts v Canada, [1989] 1 SCR 322 [Roberts]. In Roberts, it was asserted that while Aboriginal title pre-dated colonization by the British and survived British claims of sovereignty, the Aboriginal right of occupation and possession continued only as a "burden on the radical or final title of the Sovereign" (ibid at 340). How the Sovereign achieved sovereignty, in the absence of conquest or submission, was not discussed.

Van der Peet, supra note 111 at para 30.

The Wik Peoples $v$ Queensland (1996), 187 CLR 1 at 51 (HCA)

AWB Simpson, A History of The Land Law, 2nd ed (Oxford: Oxford University Press, 1986) at 107-108; RE Megarry \& HWR Wade, The Law of Real Property, 5th ed (London: Stevens \& Sons, $1984)$ at $849-50$.

Van der Peet, supra note 111 at 112.

Brian Slattery, "Understanding Aboriginal Rights" (1987) 66 Can Bar Rev 727 at 729 [Slattery, "Aboriginal Rights"]; B Slattery, "Aboriginal Sovereignty and Imperial Claims" (1991) 29:4 Osgoode Hall LJ 681 [Slattery, "Sovereignty"]; Kent McNeil, Common Law Aboriginal Title (Oxford: Clarendon Press, 1989) at 110-16, 181-83.

Battiste \& Henderson, supra note 98 at 212. 
priests, and European settlers described the First Nations people as having very few health problems. ${ }^{128}$ Studies done on First Nations bones and teeth have shown that prior to European contact, they were healthy with very few diseases. ${ }^{129}$ It was not until First Nations people came into contact with European settlers that their health depreciated drastically. ${ }^{130}$ Academic Lesley Malloch summarizes this shift:

Since the coming of the White man, we have put aside many of our ways, and we have forgotten the teachings of Mother Earth. We no longer eat the natural foods we were meant to - we eat White man's food, full of sugar and chemicals. We no longer drink pure water - we drink black tea and coffee, even alcohol. Many other things have been forgotten. This is why we have become sick and weak. ${ }^{131}$

Moreover, as noted by the Supreme Court in Delgamuukw, ${ }^{132}$ when the British sovereign asserted jurisdiction over Aboriginal lands, these Aboriginal legal regimes and their peoples were thereby protected. Throughout North America and particularly in Canada, women traditionally held important social, economic, political, and cultural roles. It has often been stated that as historians, healers, life-givers, and transmitters of culture, women's rights and well-being are essential to the survival of Aboriginal peoples. Fundamental to the growth of the Aboriginal nation was the health and strength of the women in a gender balanced society. The evidence concerning gender equality and healing systems practiced by Aboriginal peoples demonstrates that such ceremonies and practices were a distinct and integral part of Aboriginal societies. ${ }^{133}$ Accordingly, the source of Aboriginal women's health rights is rooted within traditional Aboriginal knowledge, language, and laws. As such, it follows that any Aboriginal women's right to health must be protected by virtue of its distinct and integral part of Aboriginal society, ${ }^{134}$ and it flows into section 35(4) rights.

Essential to Aboriginal societies was the maintenance of good health and a balance of male and female roles. Aboriginal peoples have complex and diverse societies, which include medical and healing traditions that pre-date European contact. The inherent right to health and health care practices have been said to be simply one manifestation of a broad-based bundle of Aboriginal rights ${ }^{135}$ and, therefore, fall within Slattery's analysis of the nature of generic rights.

Report of the Royal Commission on Aboriginal Peoples: Gathering Strength, vol 3 (Ottawa: Canada Communication Group, 1996), "Health and Healing" (quoting Nicholas Denys (1672)), cited in Yvonne Boyer, First Nations, Metis, and Inuit Health and the Law: A Framework for the Future (Saskatoon: Purich Publishing, 2014) at $\mathrm{n} 53$.

James Waldram, D Ann Herring \& T Kue Young, Aboriginal Health in Canada, Historical, Cultural, and Epidemiological Perspectives (Toronto: University of Toronto Press, 1995) at 23. Ibid.

Lesley Malloch, "Indian Medicine, Indian Health: Study Between Red and White Medicine"(1989) 10:2 \& 3 Can Women's Studies 105 at 106.

132 Delgamuukw, supra note 107 at 133-34.

133 RCAP, supra note 4 at 348 (selected contemporary writings capture understandings of Aboriginal women in the community; however, earlier writings regarding Aboriginal women were undertaken by non-Aboriginal men. As such, Aboriginal women were portrayed as wanton or undesirables or often not mentioned by the authors of the material. This created a vacuum that ultimately portrayed Aboriginal nations based on hierarchal notions where women were viewed as excluded from participation or decision -making of the community. The denigration of Aboriginal women's status in the community via the colonizers lens has left the inaccurate and mistaken impression that Aboriginal women's health was not worthy of historical significance). 
The rights within the practices and traditions reflect the distinctive cultures of Aboriginal groups. These practices operated before the assertion of British sovereignty in treaties or proclamations and they existed before the introduction of British common law. ${ }^{136}$ These practices are unique to Aboriginal people - they existed in 1982 when section 35 was enacted, and are, therefore, recognized and affirmed in their "full form."

The test articulated by the Supreme Court in Sparrow further supports the existence of gender equality within the bundle of Aboriginal rights. ${ }^{137}$ In Sparrow, the Supreme Court of Canada stated that the interpretation of Aboriginal cultures must be done in a sensitive manner, respecting the way that Aboriginal peoples view their rights. Evidence concerning women's roles in ceremonies and healing practices demonstrates that such ceremonies, practices, and rites of passage were integral to the existence of Aboriginal society. ${ }^{138}$ It may then be said that the practice of medicine, healing, and preventative health measures comprised a vital facet or integral part of a distinctive culture or were of central significance to Aboriginal society, which has passed from generation to generation in various forms and is still in existence today in modified forms. Similarly, as noted earlier, the status that women held within these societies was also integral to the existence of the Aboriginal society and supports the existence of an Aboriginal right to equality for males and females within the bundle of Aboriginal rights as constitutionalized in section 35(4).

The Supreme Court continued to refine the meaning of Aboriginal rights through decisions such as R. v. Sappier; R. v. Gray. ${ }^{139}$ In Sappier and Gray the Court focused on seeking the significance of a resource to the Aboriginal lifestyle, thus creating a restriction on the exercise of Aboriginal rights. ${ }^{140}$ The Court recognized the Aboriginal right to harvest for domestic uses and rejected any "commercial dimension" to harvest. The Court held that the Aboriginal right must be protected to preserve Aboriginal society. The Court accepted the evidence of a Mi'kmaq historian, and they acknowledged the importance of recognizing harvesting as an Aboriginal right, although in this case, there was no evidence of it being a pre-contact practice.

The Sappier and Gray decision also addressed some of the problems that have arisen since the Van der Peet "integral to a distinctive culture" requirement. There was some thought that the "distinctness" demanded in Van der Peet had to be different from other cultures (that is, not practiced by other people). Because many societies historically harvested wood, the central issue in Sappier and Gray was whether or not the harvesting of wood for survival purposes (to provide shelter) is central to the Mi'kmaq's distinctive cultures and, if so, then it is an Aboriginal right. The Court noted the differences in the terms "distinctive" versus "distinct." "141 To be considered distinct, the Court asserts that harvesting timber would have to be seen as unique to that aboriginal community (as compared to other communities), whereas distinctive would mean that harvesting wood must be of "central significance" to

Slattery, "Aboriginal Rights," supra note 126 at 737-38; Slattery, "Sovereignty," supra note 126 at 681-703; McNeil, supra note 126 at 110-16, 181-83. Sparrow, supra note 109 at $182-83$.

See e.g. Arctic College Nunavut, Interviewing Inuit elders (Iqaluit: Nunavut Arctic College, 2000), especially Volume 4: Cosmology and Shamanism and Volume 5: Health Practices. [2006] SCC 54, [2006] 2 SCR 686 [Sappier and Gray]. Ibid.

R v Marshall; $R$ v Bernard, [2005] SCC 43, [2005] 2 SCR 220 at paras 129-30 [Marshall and Bernard]. 
the community culture (regardless of whether other communities do the same). The Court found that the Mi'kmaq "culture" focuses on the pre-contact way of life, which includes their "means of survival, their socialization methods, their legal systems, and, potentially, their trading habits." 142 The Court also confirmed the Sparrow requirement that the (noncommercial) right may be carried out in a modern form and not frozen in time. The historical fact that wood was used in pre-contact days to create temporary structures "must be allowed to evolve into a right to harvest wood by modern means to be used in the construction of a modern dwelling." "143 This finding was re-affirmed in the Supreme Court of Canada case Lax Kw'alaams Indian Band v. Canada (Attorney General). ${ }^{144}$

More recently, in the case of Hamilton Health Services v. D.H., the Ontario Court of Justice held that the mother of an eleven year old Aboriginal girl, who had been diagnosed with leukemia, possessed the inherent Aboriginal right to pursue traditional medicine instead of chemotherapy for her daughter in accordance with section 35 of the Constitution Act. The use of traditional medicines during the pre-contact period was demonstrated through a Haudenosaunee creation story. ${ }^{145}$ In their reasoning, the Court also cited an academic paper that explained the integral nature of these practices, which explained that traditional ceremonies and practices had enabled Indian people to survive. ${ }^{146}$ In their final holding, the Court stated: 'It is this court's conclusion therefore, that D.H.'s decision to pursue traditional medicine for her daughter J.J. is her aboriginal right. Further, such a right cannot be qualified as a right only if it is proven to work by employing the western medical paradigm. To do so would be to leave open the opportunity to perpetually erode aboriginal rights." 147

Certainly, Sappier and Gray and Hamilton Health Services illustrate that a practice can be an Aboriginal right even if it is related to survival - a category into which health clearly falls. Additional case law illustrates that an Aboriginal right to health has been accepted as a generic right. The courts have stepped out of the Van der Peet framework and recognized rights (specific rights) outside of the basic (generic) Aboriginal rights, and they have recognized "incidental" rights as the ability to pass the accompanying knowledge of the use of the Aboriginal right to a succeeding generation. In R. v. Côté, the issue was that of an Algonquin fisher being charged with not obtaining provincial licences to fish as well as not paying the fee to enter a provincial park. ${ }^{148}$ The Supreme Court held that freshwater fishing had been an important source of sustenance, thereby obliterating the requirement to obtain provincial fishing licences. However, the defendant had not been fishing for himself but to teach a younger generation how to fish. The Court confirmed incidental rights when "a substantive Aboriginal right will normally include the incidental right to teach such a practice, custom and tradition to a younger generation," but the Court may convict on other grounds. $^{149}$

Sappier and Gray, supra note 139 at para 45.

Ibid at para 48.

2011 SCC 56, [2011] 3 SCR 535 at para 51.

Hamilton Health Sciences Corp v DH, 2014 ONCJ 603, [2015] 1 CNLR 189 at para [Hamilton].

Ibid at para 78.

Ibid at para 81 .

[1996] 3 SCR 139.

Ibid at para 56. 
Using Slattery's generic rights analysis to interpret Van der Peet, meaning that the existence of an Aboriginal right must be specific to a definable group and the right must be distinct to that group, is not useful (and, according to Slattery, is incorrect) for recognizing a general or generic right to health. Rather, analyzing Van der Peet and Hamilton as being reflective of a generic right with distinctive specific rights may be more appropriate to establish Aboriginal health (which traditionally consisted of methods, or specific rights, to create a good state of health) under section 35(4), as this section indicates Aboriginal and treaty rights are applied equally to men and women.

While the courts recognize rights incidental to Aboriginal rights, it is reasonable to assume that Aboriginal rights are not static but generic to a genus of Aboriginal rights that can change with cultures and environments and specific rights are integral and a subcategory to Aboriginal rights. Cultural elements are interdependent, and the courts struggle to recognize that these rights are in constant change. The centrality of cultural elements cannot be tied to a specific culture (knowledge, heritage, and traditions of health care). Therefore, it may be said that the right to health and the practice of these rights are integral to all human beings. But for Aboriginal people and Aboriginal women in particular, the specialized practices, as illustrated earlier, were and are integral to their distinctive cultures, pre-contact and presovereignty.

Within the framework analysis of the sphere of constitutionally protected section 35(4) rights, based on Slattery's generic rights test, Van der Peet, Sparrow, and Hamilton it may therefore be argued that gender balance in relation to health is a section 35(4) protected Aboriginal right that can be claimed by Aboriginal women in pursuing better health laws, policies, and outcomes.

\section{Conclusion}

The right to health exists in international law and is vital for protecting and advancing the right to health of Aboriginal peoples in Canada and, in particular, the health rights of Aboriginal women. Under international law, the right to health includes a legal obligation to ensure the fulfillment of this right. ${ }^{150}$ In upholding its international and domestic commitments under the UNDHR and the UNDRIP, Canada's health care system must necessarily include a holistic, culturally appropriate, and Aboriginal-controlled model which recognizes Aboriginal traditional health practices and ecological knowledge. This latter point is supported by the fact that a culturally appropriate definition of the right to health for Aboriginal peoples includes "a more holistic view of health that reflects Aboriginal cultures and traditional ecological knowledge, and the generation of a variety of disease profiles, as health research becomes more closely oriented towards the social, spiritual, economic, and political needs of specific communities." 151 
When using a test of outcomes (substantive equality), in light of the substantive equality guarantees enshrined under section 15 of the Charter, it is necessary to look at the unequal health outcomes for Aboriginal women to see the disparities in health status in comparison to the rest of the Canadian population. These outcomes reveal that the Canadian government has failed in its constitutional obligations to Aboriginal women in Canada. Given the equality provisions in section 35(4) of the Constitution Act, 1982 and those found in the Charter, one must surely expect that Aboriginal women are entitled to the same standards of health as other Canadians.

The Supreme Court of Canada has affirmed that fiduciary obligations limit the activities and policies of the federal or provincial Crown toward Aboriginal peoples. ${ }^{152}$ The federal government continues to determine the scope of Aboriginal and treaty rights to equality and health for women, without meaningful participation from Aboriginal peoples. Ironically, the federal government's policy recognizes and affirms the government's unique constitutional obligations to Aboriginal peoples, but fails to implement these obligations to certain existing Aboriginal and treaty rights.

In particular, the Harper Government's 2012 budget severely cut the health portfolios of Aboriginal national organizations. For example, among others, both the National Aboriginal Health Organization and the Aboriginal Healing Foundation lost all their funding, and the health departments were cut from the Native Women's Association of Canada, the Assembly of First Nations, the Inuit Tapiriit Kanatami, and the Congress of Aboriginal People. The rationale the government used was that there was to be a refocus on front line services. Although front line services are critical, these cutbacks severely strained important health research. This research brings to light the impacts on the varied determinants of health and how they shape Aboriginal health and, in particular, Aboriginal women's access to health services and their health outcomes. In the absence of this information, policymakers cannot make informed decisions. The results of the health portfolio cutbacks were felt in all Aboriginal communities that did not have the means to measure the negative impacts.

The new Liberal government has committed to a "renewed relationship between Canada and Indigenous peoples, one based on trust, respect and a true spirit of cooperation." 153 The 2016 budget is a step in the right direction, with an $\$ 8.4$ billion dollar investment in programs for Indigenous peoples including education, child and family services, and on reserve health care and housing infrastructure. The Liberal government has also committed to lift the 2 percent funding cap for First Nations programs that has limited the amount of funding available for basic services like health care and education, and work to establish a new fiscal relationship that delivers sufficient, predictable, and sustained funding to First Nation communities.

152 See Tsilhqot'in Nation v British Columbia, 2014 SCC 44, [2014] 2 SCR 257 at paras 69, 119. See also, Yvonne Boyer, "First Nations, Métis and Inuit Health Care: The Crown's Fiduciary Obligation," (June 2004) Discussion Paper Series in Aboriginal Health 2, National Aboriginal Health Organization \& Native Law Centre of Canada (for a fuller discussion of the duty to consult).

153 Canada, The Department of Finance, "Budget 2016: Growing the Middle Class" (Ottawa: Department of Finance, 2016) at 22, online: <www.budget.gc.ca/2016/docs/plan/budget2016-en.pdf >. 
Canada's health policies and guidelines affecting Aboriginal peoples' health must reflect the fiduciary relationship and other guidelines that the Supreme Court of Canada has stated properly characterize Crown and Aboriginal relations. To ignore these characterizations may be a breach not only of domestic constitutional equality guarantees under section 15 of the Charter and section 35(4) of the Constitution Act, 1982, but also of the principles found in the UNDRIP and other international instruments. 
